\title{
Predictors of linear growth in the first year of life of a prospective cohort of full term children with normal birth weight
}

\author{
Valterlinda A. de O. Queiroz, ${ }^{1}$ Ana Marlúcia O. Assis, ${ }^{2}$ \\ Sandra Maria C. Pinheiro, ${ }^{3}$ Hugo da C. Ribeiro Junior ${ }^{4}$
}

\begin{abstract}
Objective: To investigate covariates that could affect the variation in mean length/age $z$ scores in the first year of life of children born full term with normal birth weight.

Methods: This was a prospective study of a cohort of mother-infant pairs recruited at public maternity units in two municipalities in the Brazilian state of Bahia, from March 2005 to October 2006. This paper reports the results for linear growth of 489 children who were followed-up for the first 12 months of their lives. A mixed-effect regression model was used to investigate the influence of covariates of mean length/age $z$ score during the first year of life.

Results: The multivariate mixed effect analysis indicated that mothers not cohabiting with a partner $(\beta=0.2347$; $p=0.004)$ and increased duration of exclusive breastfeeding $(\beta=0.0031 ; p<0.001)$ had a positive impact, whereas mother's height less than $150 \mathrm{~cm}(\beta=-0.4393 ; p<0.001)$, birth weight of $2,500-2,999 \mathrm{~g}(\beta=-0.8084$; $p<0.001)$ and anemia in the child $(\beta=-0.0875 ; p<0.001)$ all had a negative impact on the variation in estimated length/age $z$ score.

Conclusions: Therefore, the results of this study indicate that short maternal stature, birth weight $<3,000 \mathrm{~g}$ and anemia in the infant had a negative effect on linear growth during the first year of life, whereas longer duration exclusive breastfeeding and mothers who did not cohabit with a partner had a positive effect.
\end{abstract}

J Pediatr (Rio J). 2012;88(1):79-86: Infant growth, predictors, mixed effect models, cohort study.

\section{Introduction}

Human growth is a continuous process which assumes different characteristics in each stage of the life cycle and is influenced by endogenous factors comprising of biological, genetic and ethnic determinants and by exogenous factors such as nutritional, cultural, environmental and social conditions. ${ }^{1}$
Growth velocity is significantly more rapid during the first 2 years of a child's life. This is the period of greatest vulnerability to growth disorders and assessment of growth with reference to the norm is one of the best indicators of infant health. ${ }^{2}$

1. Doutoranda, Pós-Graduação em Medicina e Saúde, Universidade Federal da Bahia (UFBA), Salvador, BA, Brazil. Professora, Escola de Nutrição, UFBA, Salvador, BA, Brazil.

2. Doutora, Nutrição. Professora, Escola de Nutrição, UFBA, Salvador, BA, Brazil.

3. Mestre, Estatística. Professora, Universidade Federal do Recôncavo da Bahia (UFRB), Cruz das Almas, BA, Brazil.

4. Pediatra. Professor, Pós-Graduação em Medicina e Saúde, UFBA, Salvador, BA, Brazil.

No conflicts of interest declared concerning the publication of this article.

Financial support: Conselho Nacional de Desenvolvimento Científico e Tecnológico (CNPq; processo n 505971/04-6), Centro Colaborador em Alimentação e Nutrição Região Nordeste II/MS, and Fundação de Amparo à Pesquisa do Estado da Bahia (FAPESB).

Suggested citation: Queiroz VA, Assis AM, Pinheiro SM, Ribeiro Jr HC. Predictors of linear growth in the first year of life of a prospective cohort of full term children with normal birth weight. J Pediatr (Rio J). 2012;88(1):79-86.

Manuscript submitted May 19 2011, accepted for publication Sep 192011.

http://dx.doi.org/10.2223/JPED.2143 
Linear growth deficits during the first years of life have both short and long term repercussions, including greater susceptibility to infections ${ }^{3}$ and attenuated cognitive development. ${ }^{4}$ They also lead to reduced height, ${ }^{5}$ reduced capacity to work $^{6}$ and increased risk of obesity ${ }^{7}$ in adulthood.

The importance of linear growth during early childhood and its repercussions throughout life mean that there is a need for more precise estimates of normal growth patterns in this phase of life, based on the results of studies that include means to control for intra-child and inter-child variability. However, studies with these characteristics are rare. Therefore, this cohort study employed an appropriate design and appropriate statistical methods to achieve the objective of investigating covariates that may have an impact on the variation in mean length/age $z$ scores (LAZ) during the first year of life of children born full term with normal weight.

\section{Methods}

This prospective cohort study investigated motherchild pairs who took part in the project "Breastfeeding and complementary feeding at weaning - health and nutritional status during the first 2 years of life," which was a cohort study conducted in the Brazilian municipalities of Laje and Mutuípe, are located 235 and $220 \mathrm{~km}$ from the city of Salvador, respectively. Both are part of the Recôncavo Sul region of the state of Bahia and they have a combined population of 42,280 inhabitants. The regional economy is predominantly agricultural and a majority of the population work in rural areas.

The sample recruited for this study comprised 489 infants newly born to mothers who were residents of one of the two municipalities. All infants had birth weight $\geq 2,500 \mathrm{~g}$, gestational age $\geq 37$ weeks and had suffered no intercurrent conditions during delivery. They were born at one of other of the only two public maternity units in these municipalities, 200 in Laje and 289 in Mutuípe, between March of 2005 and October of 2006, and they comprise a dynamic cohort that was followed-up for 12 months.

Multiple births ( $n=2$ ), infants born to mothers from other municipalities $(n=23)$, refusals $(n=4)$ and children with health problems that made follow-up impossible $(n=2)$ were all excluded.

This sample had $99.6 \%$ power $(1-\beta)$ to evaluate the linear growth of the children involved.

Mothers were informed of the study objectives and invited to take part. Those that agreed to take part signed free and informed consent forms; illiterate mothers gave consent by providing a finger print.
Study variables subject to change over time were recorded at birth and monthly up to 6 months of age and then every 6 months thereafter.

Birth weight was measured by maternity unit staff and length was measured by a nutritionist from the research project. All other measurements, with the exception of those taken at the first-month home visit, were taken by project staff at a health center. When mothers failed to attend for follow-up appointments, the project team visited them at home for data collection.

Children were weighed using a Filizzola digital balance with $15 \mathrm{~kg}$ capacity and $10 \mathrm{~g}$ precision. Length was measured using a wooden infantometer that had undergone reproducibility testing for a previous study. ${ }^{8}$ Anthropometric measurements were taken in duplicate using standardized techniques. ${ }^{9}$ Maximum acceptable variations were defined as $0.1 \mathrm{~cm}$ for length and $10 \mathrm{~g}$ for weight.

Hemoglobin concentration was evaluated using a portable hemoglobin meter (HemoCue Ltd.). Hemaglobin at birth was assayed in cord blood while all subsequent samples were taken by fingerstick.

Anthropometric variables and information on morbidity and dietary intake were collected at every contact with the mothers. Information on socioeconomic, demographic and environmental characteristics subject to change over time were collected at the first home visit and at the health center at the end of follow-up.

The length at all ages was converted to an LAZ, using the World Health Organization growth curves as a reference. ${ }^{10}$ Mean LAZ over the follow-up period is the dependent variable of this study. The cutoff point adopted to classify children as having growth deficit was a $z$ score of $<-2 .{ }^{11}$

The exposure variables cover a range of factors that could interfere in a child's growth. Therefore, for the exploratory analysis, variables related to the socioeconomic and demographic conditions of the family and to sanitary conditions were combined to create an environmental index. This index was constructed using eight duly weighted items (sewage/septic system, waste disposal, existence/absence of taps/faucets, drinking water supply, existence/absence of kitchen, type of walls, number of inhabitants per room and existence/absence of bathroom) that indicate the sanitary conditions of the residence and was adapted from a study conducted by Oliveira et al. ${ }^{8}$ Each item was scored with the most favorable response given 4 points and the most unfavorable given zero points. The index was subdivided into terciles and environmental conditions classified as inadequate ( $\leq 15$ points), semi-adequate (16-24 points) or adequate ( $\geq 25$ points) on the basis of the total score.

Variables related to maternal characteristics included educational level, age, height and vitamin A supplementation immediately after birth (a single dose of 200,000 UI in the maternity unit). 
The variables related to the infants were sex, birth weight, supplementation with vitamin A (a 100,000 UI dose between 6 and 11 months), age, total duration of exclusive breastfeeding the first 6 months of life (in days), diarrhea, anemia and admissions. Birth weight was categorized as 2,500 to $2,999 \mathrm{~g}$ or $\geq 3000 \mathrm{~g}$. Infants were defined as exclusively breastfed if they were exclusively fed on breastmilk, including expressed breastmilk, with the only exception permitted being oral medications and vitamins. ${ }^{12}$ Diarrhea was defined as three or more loose or liquid evacuations in a 24-hour period, according to the mother. This definition was not considered applicable to children on exclusive breastfeeding. Newborn infants were defined as anemic at birth if hemoglobin was less than 13.5 $\mathrm{g} / \mathrm{dl}$; at 2 to 5 months anemia was defined as hemoglobin below $9.5 \mathrm{~g} / \mathrm{dl}$; and at 6 to 12 months as hemoglobin less than $11 \mathrm{~g} / \mathrm{dl} .13$

The children in the sample were compared in terms of the main variables using the chi-square test. Comparisons were also made between those lost to the sample and those followed-up to the end of the study period. Fisher's exact test was used whenever a category contained less than 5 subjects.

The mixed effect model was adopted in this study since it is appropriate for assessment of growth trends in followup studies that take repeated measures from the same individuals over time and takes account of correlations between these measures, making it possible to estimate variation against a baseline measure and rate of change over time. ${ }^{14}$

Initially, bivariate analyses were conducted in order to explore individual associations between covariates and estimated mean LAZ. Variables with $p<0.20$ in the initial analysis were selected for inclusion in the multivariate analysis.

For the multivariate analysis, several models were adjusted and at each step the variable with the highest $p$ value was excluded until only variables with associations at $p<0.05$ remained and were selected for the final model. The Akaike information criterion was used to define the best adjusted model.

Data were double-input to Epi-Info 6.0. The anthropometric indices were generated using WHO Anthroplus 3.1.0. SPSS 13.0 was employed for descriptive analyses and SAS 9.0 for exploratory analyses.

The study protocol was approved by the Research Ethics Committee at Maternidade Climério de Oliveira, belonging to the Universidade Federal da Bahia (protocol number 74/2005), in accordance with Brazilian Ministry of Health resolution 196. In line with ethical practice, all mothers or children who were suffering from health problems were referred to health services and all of the mothers were given pamphlets containing guidance on nutrition for lactating women and their children. ${ }^{15}$

\section{Results}

A total of $116(23.7 \%)$ of the 489 pairs potentially eligible for the sample did not complete follow-up. However, comparison of the distribution of variables among children who were followed-up to study completion and those who were lost to follow-up revealed no statistically significant differences (data not shown).

Mean gestational age of the cohort was $39.3( \pm 1.8)$ weeks; mean birth weight was $3,229.1 \mathrm{~g}( \pm 402.4)$ and mean length was $48.5 \mathrm{~cm}( \pm 1.8)$.

Socio-environmental, demographic, maternal and infant variables are given in Table 1.

Mean estimated LAZ over the 12-month period was -0.3279 (standard deviation $=1.009$ ). At birth the mean was -0.5758 , which is the point at which the sample was furthest from the reference population's length-for-age. The $z$ score increased over the first 4 months (Figure 1a).

When anthropometric status was analyzed over the 12-month period, it was observed that the prevalence of growth deficit was 5.2\%, with a higher prevalence at birth (7.9\%) (Figure 1b).

During the first month of life, $73.4 \%$ of the children were exclusively breastfed. There was a continuous and systematic drop off of exclusive breastfeeding prevalence over the first 6 months (Figure 1c). The prevalence of diarrhea was greatest at 12 months, while anemia percentage peaked during the sixth month (Figure 1d and $1 \mathrm{e})$.

The results of the bivariate analyses indicated that low maternal educational level, inadequate environmental conditions at home, birth weight 2,500-2,999 g, maternal height $<150 \mathrm{~cm}$ and anemia in the child all inhibited linear growth during the first year of the child's life (Table 2).

The results of the multivariate analysis indicated that mothers not cohabiting with partners and greater exclusive breastfeeding duration were variables that made a positive and significant contribution to estimated mean LAZ, whereas mother's height $<150 \mathrm{~cm}$, birth weight of 2,500-2,999 $\mathrm{g}$ and anemia had negative and significant impacts (Table 3).

\section{Discussion}

Against a background of a paucity of cohort studies, this investigation provides longitudinal information including temporal and dynamic variations resulting from risks that compromise children's anthropometric status during their first year of life. This is the most significant phase ${ }^{2}$ and the period during which children are most vulnerable to morbidity and to the effects of social, economic and sanitary environment on health and nutritional status. 
Table 1 - Socio-environmental and demographic variables and characteristics of mothers and infants (Mutuípe and Laje, 2005-2007)

\begin{tabular}{|c|c|c|}
\hline Variables & $\mathbf{n}$ & $\%$ \\
\hline \multicolumn{3}{|l|}{ Environmental index } \\
\hline Adequate & 157 & 32.1 \\
\hline Semi-adequate & 161 & 32.9 \\
\hline Inadequate & 171 & 35.0 \\
\hline \multicolumn{3}{|l|}{ Sex of head of family } \\
\hline Male & 383 & 78.3 \\
\hline Female & 106 & 21.7 \\
\hline \multicolumn{3}{|l|}{ Educational level of head of family* } \\
\hline High school/higher education & 114 & 23.9 \\
\hline Primary school & 183 & 38.4 \\
\hline Illiterate & 180 & 37.7 \\
\hline \multicolumn{3}{|l|}{ Cohabiting with partner } \\
\hline Yes & 344 & 70.3 \\
\hline No & 145 & 29.7 \\
\hline \multicolumn{3}{|l|}{ Number of children under 5} \\
\hline$\leq 2$ & 433 & 88.5 \\
\hline$\geq 3$ & 56 & 11.5 \\
\hline \multicolumn{3}{|l|}{ Mother's educational level* } \\
\hline Senior high school/higher education & 113 & 23.2 \\
\hline Junior high school & 171 & 35.0 \\
\hline Illiterate/primary school & 204 & 41.8 \\
\hline \multicolumn{3}{|l|}{ Age of mother (years) } \\
\hline$\geq 20$ & 336 & 68.7 \\
\hline$<20$ & 153 & 31.3 \\
\hline \multicolumn{3}{|l|}{ Mother's height $(\mathrm{cm})$} \\
\hline$\geq 150$ & 442 & 90.4 \\
\hline$<150$ & 47 & 9.6 \\
\hline \multicolumn{3}{|l|}{ Mother received vitamin A supplementation } \\
\hline Yes & 252 & 51.5 \\
\hline No & 237 & 48.5 \\
\hline \multicolumn{3}{|l|}{ Sex of child } \\
\hline Male & 268 & 54.8 \\
\hline Female & 221 & 45.2 \\
\hline \multicolumn{3}{|l|}{ Birth weight } \\
\hline $2,500-2,999 \mathrm{~g}$ & 151 & 30.9 \\
\hline$\geq 3,000 \mathrm{~g}$ & 338 & 69.1 \\
\hline \multicolumn{3}{|l|}{ Child received vitamin A supplementation } \\
\hline Yes & 305 & 62.4 \\
\hline No & 184 & 37.6 \\
\hline \multicolumn{3}{|l|}{ Admission during first year of life ${ }^{+}$} \\
\hline No & 311 & 73.3 \\
\hline Yes & 113 & 26.7 \\
\hline
\end{tabular}

* One interviewee did not know the answer.

† 65 lost to follow-up.

Notwithstanding, the majority of studies that investigate the determinants of child growth adopt cross-sectional study designs, which, as result of intrinsic limitations, are incapable of identifying the dynamics of growth during infancy. Furthermore, they use anthropometric deficits as their dependent variable rather than the increment due to growth.
This situation led Romani \& Lira ${ }^{16}$ to point out the need for investigations of infant growth that have longitudinal designs based on the assumption of temporality and that offer improved precision for inferences of causality.

The mean LAZ over the first 12-month period of the lives of the children studied here were within the limits of healthy growth. Nevertheless, a trend was observed for 

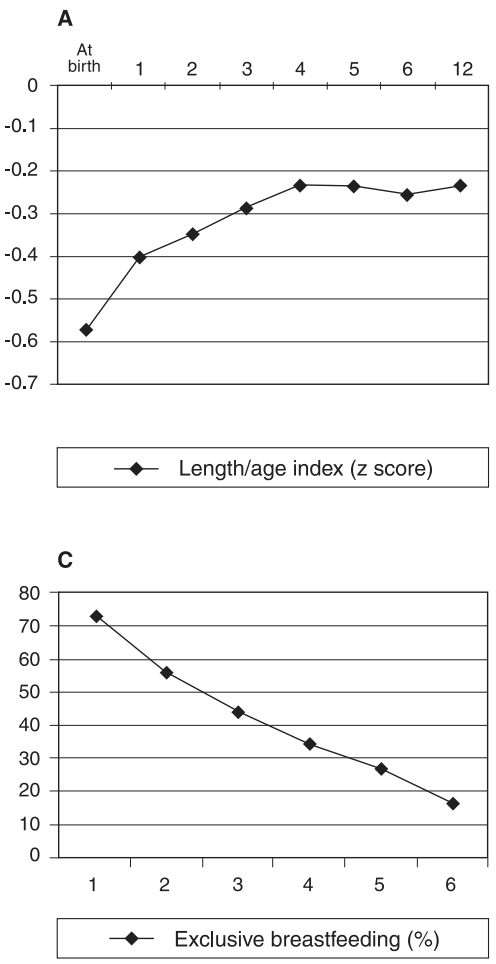

\section{E}

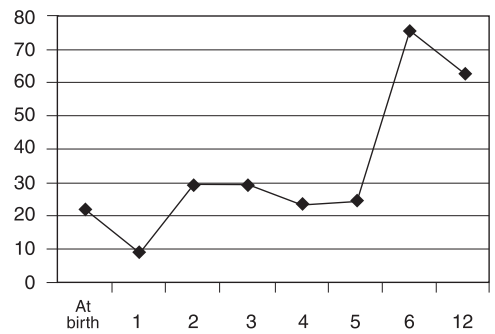

$\rightarrow$ Anemia (\%)

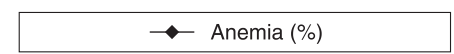

B
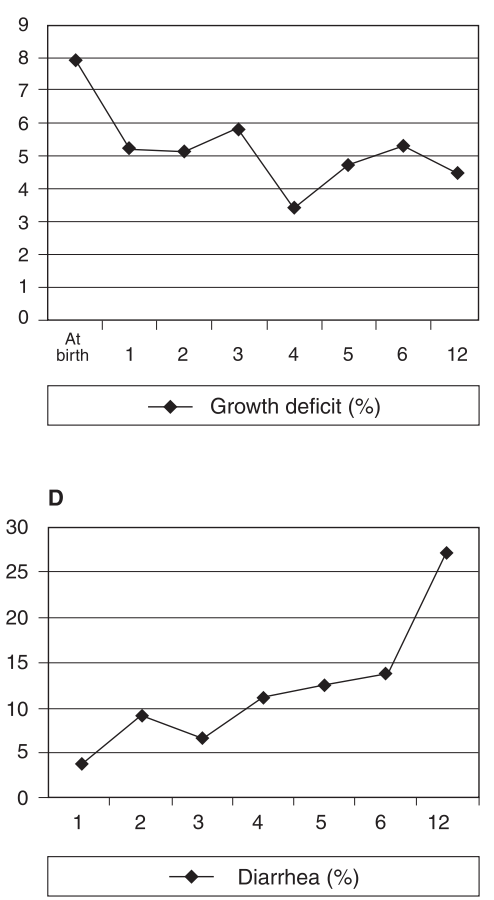

Figure 1 - Behavior of variables subject to change over the follow-up period (Mutuípe and Laje, 2005-2007)

accelerated growth up to approximately the fourth month, with a slow deceleration thereafter, up to the end of the 12-month follow-up. The results of a cohort recruited in municipalities in the Brazilian state of Pernambuco showed a deceleration at a later point. ${ }^{17}$

When variables that could possibly interfere with mean $z$ score for length/age were analyzed, it was observed that the effect of the mother not cohabiting with a partner was positive. There is no consensus in the literature on this point. Some authors have observed that cohabiting with a partner is favorable for the child's growth, ${ }^{18}$ whereas others did not report this association. ${ }^{17}$
One possible explanation for this finding is that the mothers who did not cohabit with a partner were living in extended families, very often living with elderly family members who contributed to the family income, which is a common situation in the Brazilian context, particularly in the country's Northeast region. In this region, $46.1 \%$ of the elderly live with their children, ${ }^{19}$ which, to a certain extent, could be playing a protective role for the health and nutrition of children, in particular because of the financial support they provide.

Growth deficits, especially during the first 2 years of life, can lead to irreversible damage in adulthood. The results 
Table 2 - Results of bivariate analyses of length/age index of children against selected variables during the first year of life (Mutuípe and Laje, 2005-2007)

\begin{tabular}{|c|c|c|c|}
\hline \multirow[b]{2}{*}{ Variables } & \multicolumn{3}{|c|}{ Variation in LAZ } \\
\hline & Estimate & SE & $\mathbf{p}$ \\
\hline \multicolumn{4}{|l|}{ Environmental index } \\
\hline Semi-adequate & -0.0410 & 0.1010 & 0.684 \\
\hline Inadequate & -0.2095 & 0.0995 & 0.035 \\
\hline \multicolumn{4}{|l|}{ Sex of head of family } \\
\hline Female & 0.0520 & 0.0995 & 0.601 \\
\hline \multicolumn{4}{|l|}{ Educational level of head of family } \\
\hline Primary education & -0.1160 & 0.1082 & 0.284 \\
\hline Illiterate & -0.0533 & 0.1086 & 0.623 \\
\hline \multicolumn{4}{|l|}{ Cohabiting with partner } \\
\hline No & 0.1899 & 0.0924 & 0.040 \\
\hline \multicolumn{4}{|l|}{ Number of children under 5} \\
\hline$\geq 3$ & -0.1463 & 0.1288 & 0.256 \\
\hline \multicolumn{4}{|l|}{ Mother's educational level } \\
\hline Junior high school & -0.1144 & 0.1097 & 0.297 \\
\hline Illiterate/primary school & -0.2168 & 0.1061 & 0.041 \\
\hline \multicolumn{4}{|l|}{ Age of mother (years) } \\
\hline$<20$ & -0.1170 & 0.0883 & 0.185 \\
\hline \multicolumn{4}{|l|}{ Mother's height $(\mathrm{cm})$} \\
\hline$<150$ & -0.4910 & 0.1373 & 0.000 \\
\hline \multicolumn{4}{|c|}{ Mother received vitamin A supplementation } \\
\hline No & -0.0388 & 0.0820 & 0.636 \\
\hline Age of child ( $0-12$ months) & -0.0199 & 0.0062 & 0.002 \\
\hline \multicolumn{4}{|l|}{ Sex of child } \\
\hline Female & 0.1701 & 0.0820 & 0.038 \\
\hline \multicolumn{4}{|c|}{ Child received vitamin A supplementation } \\
\hline No & 0.0575 & 0.0847 & 0.497 \\
\hline \multicolumn{4}{|l|}{ Birth weight (g) } \\
\hline $2,500-2,999$ & -0.8263 & 0.0805 & $<0.000$ \\
\hline Exclusive breastfeeding (in days) & 0.0040 & 0.0207 & 0.000 \\
\hline \multicolumn{4}{|l|}{ Diarrhea (over the 12-month period) } \\
\hline Yes & -0.0429 & 0.0310 & 0.166 \\
\hline \multicolumn{4}{|l|}{ Anemia (over the 12-month period) } \\
\hline Yes & -0.1001 & 0.0214 & $<0.000$ \\
\hline \multicolumn{4}{|l|}{ Admission during first year of life } \\
\hline Yes & -0.0037 & 0.0105 & 0.7242 \\
\hline
\end{tabular}

LAZ = length/age index (z score); SE = standard error.

Table 3 - Results of multivariate mixed effect analysis of length/age index of children during the first year of life (Mutuípe and Laje, 20052007)

\begin{tabular}{|c|c|c|c|}
\hline \multirow[b]{2}{*}{ Variables } & \multicolumn{3}{|c|}{ Variation in LAZ } \\
\hline & Estimate & SE & $\mathbf{p}$ \\
\hline Intercept & -0.3592 & 0.0549 & $<0.001$ \\
\hline $\begin{array}{l}\text { Cohabiting with partner } \\
\text { No }\end{array}$ & 0.2347 & 0.0809 & 0.004 \\
\hline $\begin{array}{l}\text { Mother's height }(\mathrm{cm}) \\
\quad<150\end{array}$ & -0.4393 & 0.1255 & $<0.001$ \\
\hline $\begin{array}{l}\text { Birth weight }(\mathrm{g}) \\
\quad 2,500-2,999\end{array}$ & -0.8084 & 0.0796 & $<0.001$ \\
\hline Exclusive breastfeeding (in days) & 0.0031 & 0.0008 & $<0.001$ \\
\hline $\begin{array}{l}\text { Anemia (over the } 12 \text {-month period) } \\
\text { Yes }\end{array}$ & -0.0875 & 0.0217 & $<0.001$ \\
\hline
\end{tabular}

LAZ = length/age index (z score); SE = standard error. 
of this study indicate that children whose mothers' height was $<150 \mathrm{~cm}$ had a negative estimated mean LAZ, when compared with the children whose mothers were taller, in line with findings reported by other authors. ${ }^{20}$ Mothers' height has been shown to be strongly associated with their children's growth, which is possibly an indication of the influence of genetic inheritance. Notwithstanding, the extent to which genetic potential is fulfilled can be affected by the socioeconomic and environmental conditions to which children are exposed. ${ }^{21}$

A birth weight of 2,500-2,999 $\mathrm{g}$ is still considered normal, but this range proved to have a negative impact on the estimated z score. A study of children born with weights < 2,999 $\mathrm{g}$ found an increased prevalence of growth deficit in the first year of life when compared with children born with weights $\geq 3,000$ g. ${ }^{22}$ Children born with deficient weight begin their growth at a disadvantage to those with normal birth weight, which is reflected in a need for increased acceleration in the velocity of anthropometric increments, ${ }^{17}$ which is a condition that often cannot be met because of the poor socioeconomic and environmental conditions to which they are exposed.

The positive effects of breastfeeding on the nutritional status of children are well-known, in particular because of the reduced incidence of infections, especially gastrointestinal and respiratory infections, and also the effect on the risk of death associated with them. ${ }^{23}$ However, the many initiatives by national and international bodies attempting to increase the duration of this feeding regime have not had the desired effect and prevalence remains low. ${ }^{24}$

In this study it was observed that the longer the duration of a child's exposure to exclusive breastfeeding during the first 6 months of life, the greater the positive impact on estimated $z$ score. These results are in line with the findings of other authors who have observed that exclusive breastfeeding during the first 6 months of life promotes faster linear growth than observed in children who are exclusively breastfed for 3 months. ${ }^{25}$

Particularly during the first months of life, hemoglobin levels are linked to the iron stocks built up during the gestational period and to a range of factors of extrauterine life. In this study, the prevalence of anemia at birth was $22.2 \%$, but the greatest percentage was observed at 6 months $(75.5 \%)$, with a reduction taking place by 12 months $(62.9 \%)$. These prevalence rates are considered elevated for all of these age groups.

The elevated prevalence of anemia during the first months of life that was identified in this study can, in part, be attributed to immediate clamping of the umbilical cord, which is the routine technique at the obstetric services in the municipalities studied here. This procedure can have a negative impact on children's iron stocks and hematological status, particularly during the first 2 to 4 months of life. ${ }^{26}$
Additional first-year risk factors for anemia include inadequate nutritional practices, which, in addition to compromising infant growth, can increase the likelihood of deficiency diseases, especially anemia. Early introduction of cow's milk was identified as a risk for anemia in infants under 6 months in this cohort, even when concurrent with breastfeeding. ${ }^{27}$ Notwithstanding, children are more vulnerable to iron deprivation from 6 to 24 months of age, especially after the start of the second 6 months of life, which is when introduction of complementary foods should begin. ${ }^{28}$ These foods are very often introduced too early and are often qualitatively inappropriate for the child. ${ }^{29}$

In this study, the greatest prevalence of anemia was observed at 6 months of age and had decreased by 12 months of age, in contrast with results from children living in the state capital Salvador, where prevalence rose from 6 to 18 months. ${ }^{30}$

In compliance with the ethical protocol for this study, all children who exhibited some type of morbidity during follow-up were referred to health services, which could partly explain the reduction in anemia prevalence from 6 to 12 months of age. In the event of anemia children were given supplementation with ferrous sulphate, except those less than 6 months old who were still on exclusive breastfeeding. Additionally, mothers were advised on the introduction of complementary foods, which may have led to them choosing more appropriate complementary foods.

In this study, anemic children exhibited a negative variation in mean $z$ score. Assis et al. observed increased likelihood of reduced hemoglobin levels among children with linear growth deficit when compared with well-nourished children. 30

Diarrhea and hospital admission are recognized as being associated with compromised linear growth. However, our findings did not reveal this association. This is possibly because the care offered to these children may have reduced the negative impact of these variables on infant growth.

It is important to point out that losses during follow-up, primarily those during the 12 months after recruitment, are a limitation to this study. This is a problem that is observed in longitudinal studies. This investigation was conducted in municipalities in Brazil's Northeast administrative region, where the majority of families live in poor socioeconomic conditions, which provokes internal migration because they live in rented accommodation or migration to other parts of the state or country in search of better living conditions, contributing to follow-up losses. Additionally, the rural areas have access problems, especially during the rainy season, when displacement of people and motorized transport becomes difficult, compromising attempts to contact children who do not attend follow-up appointments. Although losses did occur, the results of statistical analyses indicate that the distributions of variables were similar in the groups 
followed and lost, indicating that the original sample was not distorted by the losses.

Therefore, the results of this study indicate that during their first year of life, children born full term and with normal weight are exposed to many risk factors related to their family sanitary, social and cultural environments and demographic and maternal obstetric factors, in addition to those related to the care provided by the health services. Closer monitoring of these children could minimize the effects of factors that inhibit their growth, thereby guaranteeing them maximum fulfillment of their genetic potential.

\section{References}

1. Spyrides MHC, Struchiner CJ, Barbosa MTS, Kac G. Efeito das práticas alimentares sobre o crescimento infantil. Rev Bras Saúde Matern Infant. 2005;5:145-53.

2. Brasil. Ministério da Saúde. Secretaria de Políticas de Saúde. Departamento de Atenção Básica. Saúde da criança: acompanhamento do crescimento e desenvolvimento infantil. Brasília: Ministério da Saúde; 2002.

3. Victora CG, Adair L, Fall C, Hallal PC, Martorell R, Richter L, et al. Maternal and child undernutrition: consequences for adult health and human capital. Lancet. 2008;371:340-357.

4. Kossmann J, Nestel P, Herrera MG, El Amin A, Fawzi WW. Undernutrition in relation to childhood infections: a prospective study in the Sudan. Eur J Clin Nutr. 2000;54:463-72.

5. Li $H$, Stein $A D$, Barnhart $H X$, Ramakrishman $U$, Martorell R. Association between prenatal and postnatal growth and adult body size and composition. Am J Clin Nutr. 2003;77:1498-505.

6. Haas JD, Murdoch S, Rivera J, Martorell R. Early nutrition and later physical work capacity. Nutr Rev. 1996;54:S41-8.

7. Hoffman DJ, Sawaya AL, Verreschi I, Tucker KL, Roberts SB. Why are nutritionally stunted children at increased risk of obesity? Studies of metabolic rate and fat oxidation in shantytown children from São Paulo, Brazil. Am J Clin Nutr. 2000;72:702-7.

8. Oliveira VA, Assis AM, Pinheiro SM, Barreto, ML. Determinantes dos déficits ponderal e de crescimento linear de crianças menores de dois anos. Rev Saude Publica. 2006;40:874-82.

9. Lohman TG, Roche $A F$, Martorell R, editors. Anthropometric standardization reference manual. Champaign: Human Kinects Books; 1988. p. 55-70.

10. World Health Organization (WHO). Multicentre Growth Reference Study Group. Child growth standards: length/height-for-age, weight-for age, weight-for-length, weight-for-height and body mass index-for-age: methods and development. Geneva: World Health Organization; 2006.

11. World Health Organization (WHO). Child Growth Standards: training course on child growth assessment. Module $\mathrm{C}$ : interpreting growth indicators. Geneva: World Health Organization; 2008.

12. World Health Organization (WHO). Indicators for assessing infant and young child feeding practices. Part 1: definitions. Geneva: World Health Organization; 2008.

13. World Health Organization (WHO). The clinical use of blood in medicine, obstetrics, paediatrics, surgery and anaesthesia, trauma and burns. Geneva: World Health Organization; 2001.

14. Fausto MA, Carneiro M, Antunes CM, Pinto JÁ, Colosimo EA. O modelo de regressão linear misto para dados longitudinais: uma aplicação na análise de dados antropométricos desbalanceados. Cad Saude Pública. 2008;24:513-24.
15. Brasil. Ministério da Saúde. Secretaria de Política de Saúde. Organização Pan-Americana da Saúde. Dez passos para uma alimentação infantil. Guia alimentar para crianças menores de 2 anos. Brasília: Ministério da Saúde; 2002.

16. Romani SA, Lira PI. Fatores determinantes do crescimento infantil. Rev Bras Saúde Matern Infant. 2004;4:15-23.

17. Eickmann SH, Lima M de C, Motta ME, Romani S de A, Lira PI. Crescimento de nascidos a termo com peso baixo e adequado nos dois primeiros anos de vida. Rev Saúde Publica. 2006;40:1073-81.

18. Ashworth A, Morris SS, Lira PI. Postnatal growth patterns of fullterm low birth weight infants in Northeast Brazil are related to socioeconomic status. J Nutr. 1997;127:1950-6.

19. Instituto Brasileiro de Geografia e Estatística (IBGE). Síntese de indicadores sociais: uma análise das condições de vida da população brasileira. http://www.ibge.gov.br/home/estatistica/populacao/ condicaodevida/indicadoresminimos/sinteseindicsociais2010/ SIS_2010.pdf. Access: 18/06/2011.

20. Arifen SE, Black RE, Caulfield LE, Antelman G, Baqui AH. Determinants of infant growth in the slum of Dhaka: size and maturity at birth, breastfeeding and morbidity. Eur J Clin Nutr. 2001; 55:167-78

21. Silveira KB, Alves JF, Ferreira HS, Sawaya AL, Florêncio TM. Associação entre desnutrição em crianças moradoras de favelas, estado nutricional materno e fatores socioambientais. J Pediatr (Rio J). 2010;86:215-20.

22. Gigante, DP, Victora CG, Araújo CL, Barros FC. Tendências no perfil nutricional das crianças nascidas em 1993 em Pelotas, Rio Grande do Sul, Brasil: análises longitudinais. Cad Saude Publica. 2003; 19:S141-7.

23. Effect of breastfeeding on infant and child mortality due to infectious diseases in less developed countries: a pooled analysis. WHO Collaborative Study Team on the Role of Breastfeeding on the Prevention of Infant Mortality. Lancet. 2000;355:451-5.

24. Organización Mundial de la Salud (OMS); Organización Panamericana de la Salud (OPAS). La alimentación del lactante y del niño pequeño: capítulo modelo para libros de texto dirigidos a estudiantes de medicina y otras ciencias de la salud. Washington: OPS; 2010.

25. Kramer MS, Guo T, Platt RW, Sevkovskaya Z, Dzikovich I, Collet $\mathrm{JP}$, et al. Infant growth and health outcomes associated with 3 compared with 6 mo of exclusive breastfeeding. Am J Clin Nutr. 2003; 78:291-5.

26. Brasil. Ministério da Saúde. Secretaria de Atenção à Saúde. Departamento de Ações Programáticas e Estratégicas. Além da sobrevivência: práticas integradas de atenção ao parto, benéficas para a nutrição e a saúde de mães e crianças. Brasília: Ministério da Saúde; 2011.

27. Oliveira AS, Silva RCR, Fiaccone RL, Pinto E de J, Assis AM. Efeito da duração da amamentação exclusiva e mista sobre os níveis de hemoglobina nos primeiros seis meses de vida: um estudo de seguimento. Cad Saude Publica. 2010;26:409-17.

28. Hadler MC, Juliano Y, Sigulem DM. Anemia do lactente: etiologia e prevalência. J Pediatr (Rio J). 2002;78:321-6.

29. Brasil. Ministério da Saúde. Secretaria de Atenção à Saúde. Departamento de Ações Programáticas e Estratégicas. II Pesquisa de prevalência de aleitamento materno nas capitais brasileiras e Distrito Federal. Brasília: Ministério da Saúde; 2009.

30. Assis AM, Barreto ML, Gomes GS, Prado M da S, Santos NS, Santos LM, et al. Childhood anemia prevalence and associated factors in Salvador, Bahia, Brazil. Cad. Saude Publica. 2004;20:1633-41.

Correspondence:

Valterlinda A. de O. Queiroz

Rua Araújo Pinho, 32 - Canela

CEP 40110-150 - Salvador, BA - Brazil

Tel: + 55 (71) 3283.7726

Fax: +55 (71) 3283.7700

Email: valterlinda.oliveira@gmail.com 